\title{
Is gender mainstreaming helping women scientists? Evidences from research policies in Spain
}

\author{
Alba ALONSO \\ Isabel DIZ \\ Marta LOIS \\ University of Santiago de Compostela \\ alba.alonso@usc.es \\ isabel.diz@usc.es \\ martairene.lois@usc.es
}

Recibido: Junio 2016

Aceptado: Diciembre 2016

\begin{abstract}
Literature has repeatedly shown that gender mainstreaming is far from being transformative and smoothly introduced. It is rather a contested strategy, leading to steady impacts on changing routines and gendering policy outcomes. However, research policies have appeared to be one of the issues areas where a gender perspective has been introduced. This is the case for Spanish research policies, which have been assessed to promote the inclusion of women in the R\&D system. This article explores these emerging shifts in order to explore the problem for women in science and the solutions proposed to solve it. In addition, it seeks to examine whether these measures can potentially help women to get an equal position in science or whether they are addressing the wrong targets. To do so, this work draws on a survey of doctoral and postdoctoral researchers carried out in Spain, covering 350 respondents. It captures the necessities, wills and obstacles for women scientists, and while doing that, it allows us to assess whether gender mainstreaming is likely to be effective for bringing more women to the academia.
\end{abstract}

Keywords: gender, mainstreaming, academic careers, gender equality policies, research policies.

\section{¿Está ayudando el mainstreaming de género a las mujeres científicas? Evidencias en las políticas de ciencia y tecnología españolas}

\section{RESUMEN}

La literatura ha demostrado en varias ocasiones que la transversalidad está lejos de ser transformadora y que no se ha incorporado sin problemas. Más bien nos encontramos ante una estrategia discutida, que implica cambios de las rutinas y los resultados de las políticas. Sin embargo, las políticas de ciencia y tecnología parecen ser uno de los ámbitos en los que la perspectiva de género se ha introducido con éxito. Este es el caso de las políticas de 
investigación en España, que han experimentado una ligera revisión a fin de promover la inclusión de las mujeres en el sistema de I + D. Este artículo explora estos cambios emergentes con el fin de determinar cuál es el problema para las mujeres en la ciencia y qué soluciones se proponen para resolverlo. Además, se busca determinar si estas medidas pueden ayudar potencialmente a las mujeres a conseguir una posición de igualdad en la ciencia o si se está persiguiendo el objetivo equivocado. Para hacerlo, esta investigación se basa en una encuesta realizada a estudiantes de doctorado y posdoctorado llevada a cabo en España, sobre una muestra 350 personas encuestada. . A partir de estos datos podemos saber cuáles son las necesidades reales, expectativas y obstáculos de las científicas, a la vez que se nos permite evaluar si la incorporación de la perspectiva de género está ayudando a que cada vez más mujeres se incorporen al mundo académico.

Palabras clave: Género, mainstreaming, trayectorias académicas, políticas públicas de género, políticas científicas.

\section{INTRODUCTION}

Women and science studies have long been devoted to unveil the extent to which gender inequalities also affect $\mathrm{R} \& \mathrm{D}$ systems. Double segregation relegating female researchers to some fields of study and to the lowest positions stands up as one of its main findings. Thus, a differential distribution of men and women both vertically and horizontally has been insistently reported, regardless country or type of organization (UNESCO, 2007; European Commission, 2006). These studies show that after the doctoral level the proportion of men and women invert, forming the so called "scissors diagram". The percentage of female researchers begins to drop immediately after graduation and falls drastically in the postdoctoral stage, the first step towards specialization and consolidation in higher education institutions. Both quantitative and qualitative analyses shed light on the impact of maternity and reproductive work on this long-standing pattern (Probert, 2005; Bailyn, 2003; Leontowitsch and VázquezCupeiro, 2003b). Additionally, organizational rules and symbols, informal networks or rituals have been described as elements bringing about diverging experiences during the academic career (Kantola, 2008; Benschop and Brouns, 2003; Elg and Jonnegargd, 2003; Deem, 2003; Leontowitsch and Vázquez-Cupeiro, 2003a).

Structural gender inequalities shaping R\&D systems call for the adoption and implementation of equality policies. Accordingly, scholars have emphasized the necessity for a gender perspective to be effectively included into research policies (Osborn et al., 2001; Rees, 2002). Generally speaking, gender mainstreaming has been a contested strategy that has rarely succeeded on triggering actual policy change (See for instance Kantola, 2010; Squires, 2007). Its policy outcomes have been rather uneven depending on the country, the level of government or the issue at stake. Curiously enough, research policies have shown some potential for the effective implementation of gender mainstreaming (Alonso, 2015; Jacquot, 2007; Mazey, 2001; Hafner-Burton and Pollack, 2000). The EU initially “carried the torch" with this regard and called in the late 90s for gender-sensitive measures to ensure research by, for, and on women (Alonso, 2015, 2016). Rapidly, the Member States echoed these patterns and incorporated gender equality as an integral objective of their research policies. 
This article contributes to these two main bodies of knowledge by addressing the case of Spain. It does so by exploring three different elements. First, it provides with a diagnosis of the situation of female young researchers. Very few studies put forth explanations of the combination of factors that have a noticeable effect at the beginning of the academic career. We believe the importance of career related decisions at this initial stage requires for studies to explore what occurs in those first decisive years. To do so, we have conducted a study whose main goal was to investigate the path of research personnel in doctoral and postdoctoral positions in Spanish Universities from a gender perspective. It draws on a survey of doctoral and postdoctoral students carried out in Spain, covering 350 respondents. This article presents some of its preliminary results thanks to an analysis of occurrences of key indicators.

Second, this work aims at contributing to the literature focused on the analysis of gender mainstreaming, by exploring how and to what extent Spanish research policies have been assessed from a gender perspective. In recent years, with the help of policies championing equal gender opportunities undertaken at all levels of government, the academic situation of women in the world of science and technology has become an important issue. This article explores these emerging shifts in order to capture the solutions proposed to tackle gender inequalities in this area, and the impact of gender mainstreaming on research policies in Spain.

Finally, this work seeks to explore whether these measures can potentially help women to get an equal position in science or whether they are addressing the wrong targets. To do so, it explores the extent to which gender-sensitive measures seem to tackle those problems previously identified in the diagnosis.

This article is structured in four parts. First, a brief review of literature on the situation of women in science is introduced. The second section discusses the most relevant findings of the study regarding research personnel with the objective of determinig differences between sexes as regards hindrances, expectancies or needs that might help understand their diverse academic paths. Next section focuses on analyzing Spanish research policies in order to determine the measures proposed in Spain. The conclusions tentatively delve into the exent to which these policies might be hitting the target and bringing more women to the academia.

\section{WHAT IS THE PROBLEM FOR WOMEN IN SCIENCE? A PRELIMINARY DIAGNOSIS}

The analysis of gender inequality in science has gained momentum in the last decades. Sex-disaggregated data and gendered diagnoses have become more and more common, providing with a world-wide state of the art. As a result, some thoroughly tested indicators have been able to insistently capture the presence of inequalities between men and women. First, vertical segregation is shown by the progressive loss of female researchers in the academic hierarchy. The EU data, for instance, unveils the high percentages of women as under-graduate and graduate students (European Commission, 2013). When focusing on their presence as PhD students, however, a 
progressive 'disappearance' can be easily perceived. The so called 'leaky pipeline' starts to work at this stage dropping women in each hierarchical level and ending up in a $20 \%$ at the top position. This reversal of percentages draws what has been labeled as the 'scissors diagram', which makes clear that a massive presence of women as students does not correspond to their vast absence as professors. Spain performs in a quite similar manner. In 2012, whilst women constituted 58'3\% of the graduate students, they only represented $39 \%$ and $19{ }^{\prime} 7 \%$ as professors Grade B and Grade A respect (Unidad de Mujer y Ciencia, 2014). What is more, under-representation was also reported for research fields such as Humanities where female students have been a majority for decades. This fact nuances the positive effect of time as a way to minimize inequalities.

Horizontal segregation refers to the unequal numbers of women in each specific field of study. In this case, the numbers of female under-graduate students remains high in the field of Social Sciences, Humanities, Medical Sciences and, to a lesser extent, in Natural Sciences. In Spain, for example, the most recent data show a significant feminization in the field of Heath Sciences, where female students have surpassed 60\% (Unidad de Mujer y Ciencia, 2011), and a more or less equal presence, between $50 \%$ and $60 \%$ in remaining fields ${ }^{1}$. The field of Engineering and Technology continues to demonstrate a high level of masculinization, and women represent only a $26 \%$ of undergraduate students in Spain. The presence of this enormous gap is evident in decisions made about specialization during secondary education, and increases progressively at each academic level.

Scholars have also devoted attention to capture inequalities as regards decisionmaking processes, as they affect crucial aspects such as the allocation of resources or the recognition of academic merit. Women are vastly under-represented at the top positions of the research and higher education institutions (European Commission, 2009). The lack of parity also affects other key structures such as evaluation committees, who are responsible for the distribution of resources in most R\&D public funding, and research teams and projects, vastly formed and led by men (European Commission, 2005).

In a different vein, scholars have also reflected on the way in which those inequalities are reproduced. First, attention has been paid to how and to what extent gender is "done" within academic institutions (Izquierdo, 2009; Benschop and Brouns, 2003; Falkenberg, 2003). Here, symbols, rituals, and rules are seen as the main vehicles through which gender is constantly constructed and reinforced (Kantola, 2008). The main consequence is for women to experience that gender inequalities represent a hindrance determining less access to resources, to academic support or to research networks -old boys networks-. Secondly, analyses highlight the crucial impact of maternity and care responsibilities on women's careers (Probert, 2005; Benschop and Brouns, 2003; Elg and Jonnegard, 2003). The academic career is meant to be progressive, break-free and highly demanding within the first stages -pre-doctoral and

\footnotetext{
${ }^{1}$ Data for the regional level is available in Guil atl al., 2005; Vázquez et al., 2009; Martínez, 2003.
} 
postdoctoral studies-, those years when maternity is more likely. Thus, part-time work and interruptions disproportionally affect women in a manner that helps reinforce gender inequalities in science.

\section{THE RESEARCH PERSONNEL AT SPANISH UNIVERSITIES: AN ANALYSIS FROM A GENDER PERSPECTIVE}

In this article, we analyse data from a research project aimed at carrying out a diagnosis of the situation of research personnel in Spanish universities. This project was funded by the Ministry of Education in 2009. Drawing on this general goal, the project sought to determine: 1) whether there are gender inequalities amongst those researchers that were recepients of a postdoctoral and predoctoral grant; 2) what kind of profiles are demonstrated by incoming research students (personnel); 3) whether there are significant differences in the academic paths of male and female researchers; 4) whether goals, concerns, and professional goals of men and women differ; and 5) whether research personnel is subject to different levels of attention based on their sex.

The methodology was primarily quantitative. First, we conducted an analysis to characterize the scope of the study. The aim was to obtain information about the following questions: 1) Are men and women recepients of grants and contracts to the same extent, or is there some sort of gender bias? ; 2) Is there a smaller proportion of women in some grants than in others?; and 3) Are there differences in the number of women according to the field of study?

The scope of study is made up of 5,079 people who participated in 8 calls carried out by the National Program for Human Resources of the Ministry of Innovation and Science (Programa Nacional de Formación de Recursos Humanos del Ministerio de Innovacion y Ciencia), in 2005 and 2008. To identify our sample universe, we used the list of recepients of the grants offered by each call published by the Ministry itself. The public calls from these years were chosen to gather opinions and perceptions of researchers in different phases of their academic career. Those researchers who had just been awarded a grant in 2005 would be completing it in 2008, resulting in the broadest possible spectrum of results.

Our scope of study is comprised of people who had benefited from the following four subprograms in the 2005 and 2008 calls: Subprogram FPI (Formación de Personal Investigador), Subprogram FPU (Formación de Profesorado Universitario), Subprogram Ramón y Cajal, and Subprogram Juan de la Cierva. Therefore, there are two distinct profiles included in this scope of study.

On the one hand, the recipients of the FPI and FPU were still in the process of writing and defending their thesis, when they got the aforementioned grants. On the other hand, the recipients of the Ramon y Cajal and the Juan de la Cierva had already obtained their doctorate degree. Likewise, in order to analyze the criteria for acceptance and the conditions of the contracts, the programs have to consider the differences between the conditions offered to the research personnel. It is important to 
look at both the salary and the duration of the contract, and the fact that the programs of Ramon y Cajal enjoy greater prestige.

The second fundamental part of the research consisted of analyzing external factors that have an effect on the academic career of research personnel in Spain. To this end, our data collection method consisted of designing a questionnaire ${ }^{2}$ customized for the research population. Once defined, we designed the sample by establishing 10 strata, using a combination of the two criteria for stratification: gender and field of study. To reduce errors in estimation in each strata and to ensure that no section is underrepresented, the data is presented proportionally. A simple random sample was extracted from each stratus and was formed by 354 respondents.

The fieldwork was undertaken in a period of ten weeks. Firstly, the research team contacted the persons included in the sample by phone in order to explain the aims of the study and request their contribution. Secondly, the questionnaire was sent by email to all the respondents. The response rate was 54,9\%. The diagnosis carried out allowed us to draw a few preliminary and tentative conclusions.

\section{ACCESS TO PREDOCTORAL AND POSTDOCTORAL GRANTS}

The leaky pipeline is an excellent metaphor to summarise the gendered access to both pre and postdoctoral grants in our field of study.

Graph 1. Predoctoral and postdoctoral grant according to sex

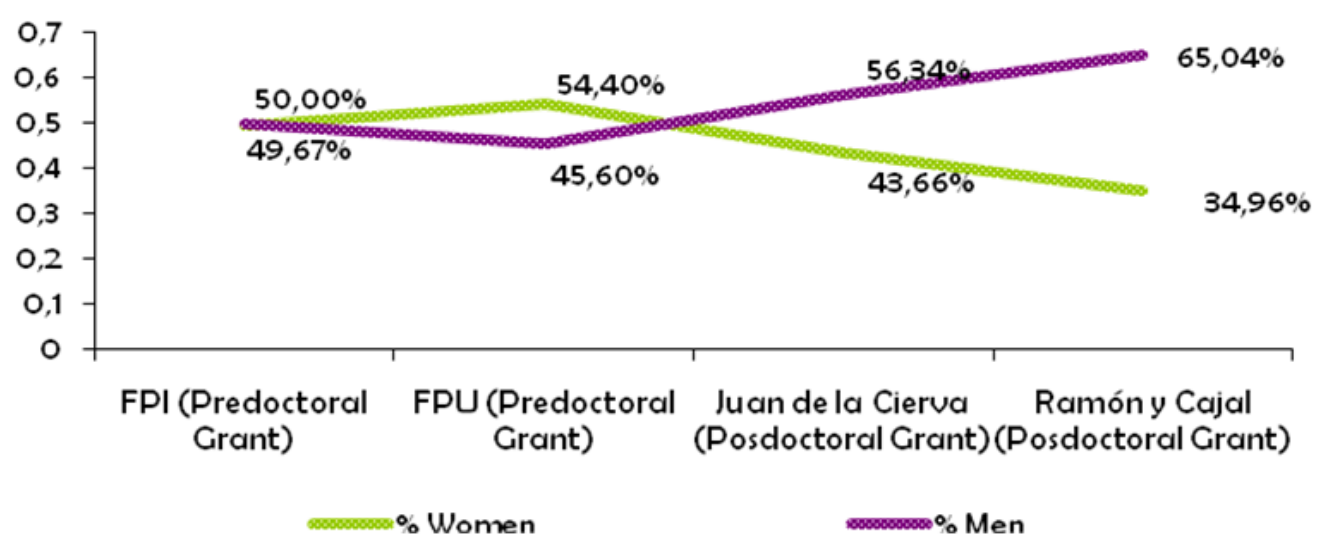

\footnotetext{
${ }^{2}$ The process of drafting the questionnaire included the analysis of existing literature and information gleaned from other questionnaires carried out in Spain. The questionnaire included 50 questions organized into blocks. Each one addressed a different part of the academic career (undergrad, doctoral, postdoctoral, and work experience both in university and in the labor market). Other questions addressed expectations about the future, socioeconomic profiles, and family matters. The questions for each stage of the academic career reflect the researcher's current situation, his/her perception of the obstacles and motivations he/she encounters, and his/her expectations.
} 
The underlying idea of this concept, as we see in Graph $1^{3}$, is the steady loss of women. In the Ramon y Cajal grant, which is considered to be the most prestigious, we find the smallest proportion of women.

In the most feminized fields of study, we see the greatest loss of women (Graphs 2 and 3). The differences in regard to the type of academic trajectory and the factors that determine these dissimilarities, both arbitrary and standardized, represent possible explanations for this phenomenon.

Graph 2. Distribution of predoctoral grant by sex and field of study

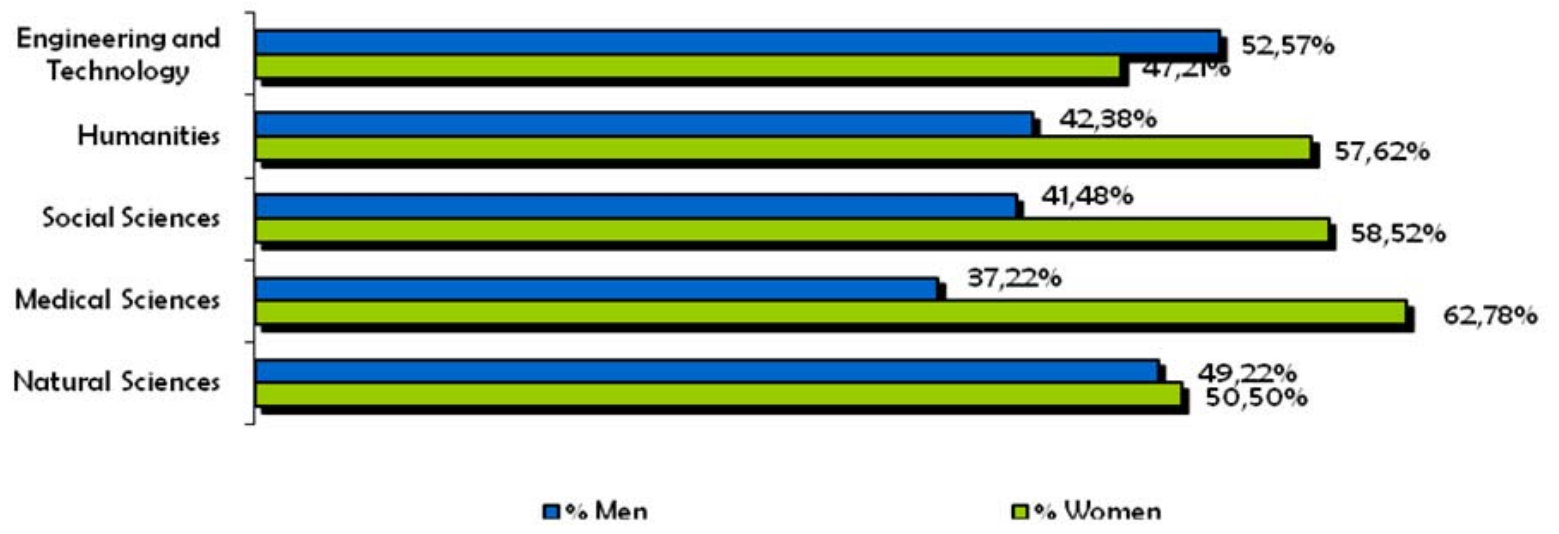

Graph 3. Distribution of postdoctoral contracts by sex and field of study

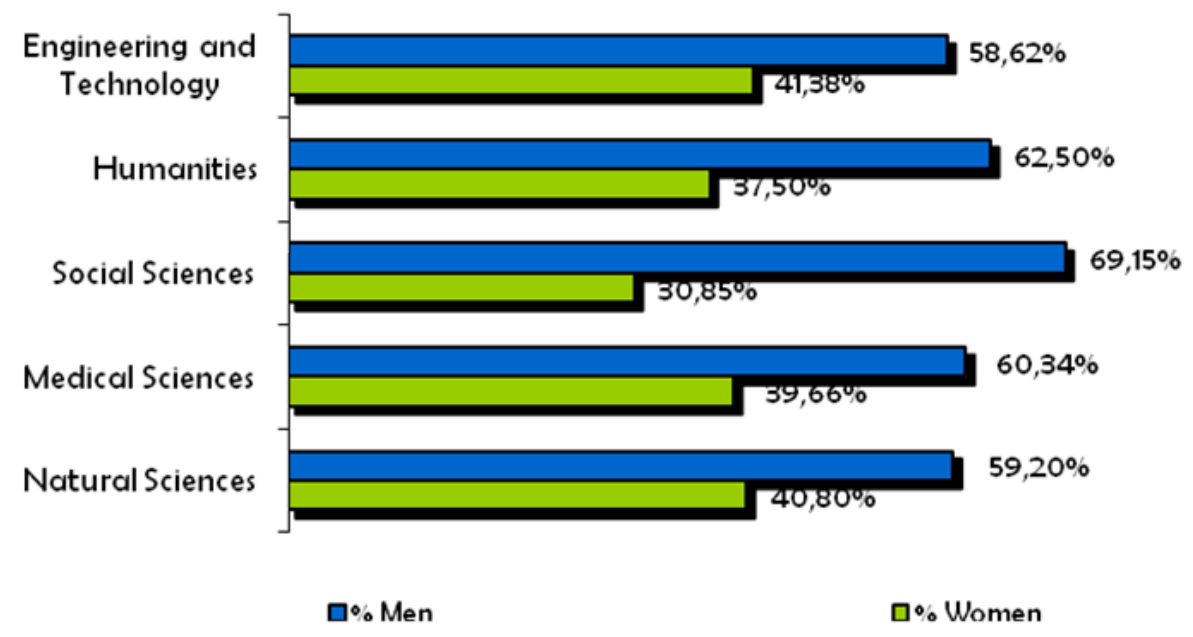

On the other hand, if focusing on possible indicators of discrimination against women, the leaky pipeline goes in line with a slowing down of the academic career, suggested by the average age of male and female researchers. When analysing the age

${ }^{3}$ Data included in graphs 1, 2 and 3 refers to the sample universe. Other data presented here corresponds to the respondents. 
of the respondents at the time the study was conducted, data shows that the youngest group is that of female predoctoral grant holders, with an age average of 27,9 years old, whereas the oldest group is that of the female postdoctoral researchers, whose age average is 36,65 years old. Men from this same group feature an age average of 35,93 years old.

It is also important to point out the differences in life cycles will be reflected later in family models established by some of this personnel. In this sense, and as we see in Table 1, age, and above all the life cycle, seem to lie behind the distinct models of domestic unity that we find in research personnel. Two specific profiles stand out. On one hand, those who have chosen not to make a family. On the other hand, we have the predominant model for postdoctoral women, which is cohabitation with a partner. Similarly, as indicated in table 2, a significant proportion of these women have children: $51.28 \%$ of women with a postdoctoral grant, compared to $28.26 \%$ of men in the same position who claim to have children. For predoctoral grant holders these percentages are $4.44 \%$ and $3.73 \%$ for women and men respectively.

Table 1. Social status by sex and type of grant or contract

\begin{tabular}{|c|c|c|c|c|}
\hline & $\begin{array}{l}\text { Women } \\
\text { predoctoral grant }\end{array}$ & $\begin{array}{l}\text { Women postdoctoral } \\
\text { contract }\end{array}$ & $\begin{array}{l}\text { Men predoctoral } \\
\text { grant }\end{array}$ & $\begin{array}{l}\text { Men postdoctoral } \\
\text { contract }\end{array}$ \\
\hline \multirow[t]{2}{*}{ Single } & 103 & 12 & 111 & 27 \\
\hline & $76,30 \%$ & $30,77 \%$ & $82,84 \%$ & $61,36 \%$ \\
\hline \multirow[t]{2}{*}{ Married } & 18 & 22 & 10 & 12 \\
\hline & $13,33 \%$ & $56,41 \%$ & $7,46 \%$ & $27,27 \%$ \\
\hline \multirow{2}{*}{$\begin{array}{l}\text { Divorced } \\
\text { /Separated }\end{array}$} & 2 & 1 & 0 & 1 \\
\hline & $1,48 \%$ & $2,56 \%$ & $0,00 \%$ & $2,27 \%$ \\
\hline \multirow[t]{2}{*}{ Widow } & 1 & 0 & 0 & 0 \\
\hline & $0,74 \%$ & $0,00 \%$ & $0,00 \%$ & $0,00 \%$ \\
\hline \multirow{2}{*}{$\begin{array}{l}\text { Common } \\
\text { law parther }\end{array}$} & 10 & 4 & 11 & 4 \\
\hline & $7,41 \%$ & $10,26 \%$ & $8,21 \%$ & $9,09 \%$ \\
\hline \multirow[t]{2}{*}{ N/A } & 1 & 0 & 2 & 0 \\
\hline & $0,74 \%$ & $0,00 \%$ & $1,49 \%$ & $0,00 \%$ \\
\hline \multirow{2}{*}{ Total } & 135 & 39 & 134 & 44 \\
\hline & $100,00 \%$ & $100,00 \%$ & $100,00 \%$ & $100,00 \%$ \\
\hline
\end{tabular}


Table 2. Percentage of researchers who have children by sex and type of grant or contract

\begin{tabular}{cccccc}
\hline & & \multicolumn{5}{c}{$\begin{array}{c}\text { Sex by trype of grant or } \\
\text { contract }\end{array}$} \\
\hline & & $\begin{array}{c}\text { Women with } \\
\text { predoctoral } \\
\text { grants }\end{array}$ & $\begin{array}{c}\text { Women with } \\
\text { postdoctoral } \\
\text { grants }\end{array}$ & $\begin{array}{c}\text { Men with } \\
\text { predoctoral } \\
\text { grants }\end{array}$ & $\begin{array}{c}\text { Men with } \\
\text { postdoctoral } \\
\text { grants }\end{array}$ \\
\hline \multirow{2}{*}{$\begin{array}{c}\text { Do you have } \\
\text { children? }\end{array}$} & Yes & 6 & 20 & 5 & 13 \\
\cline { 2 - 6 } & No & $4,44 \%$ & $51,28 \%$ & $3,73 \%$ & $28,26 \%$ \\
\cline { 2 - 6 } & N/A & 125 & 18 & 126 & 32 \\
\cline { 2 - 6 } & & $42,59 \%$ & $46,15 \%$ & $94,03 \%$ & $69,57 \%$ \\
\hline Total & & 135 & 1 & 3 & 1 \\
\hline & & $100,00 \%$ & $100,00 \%$ & $100,00 \%$ & $100,00 \%$ \\
\hline
\end{tabular}

Further research is needed to explore whether those differences in the family model jeopardize the women's equal opportunities, and whether or not women are more likely to relinquish in terms of family and personal life.

\section{ACADEMIC TRAJECTORY}

Horizontal segregation represents a world-wide phenomenon in the academia. Here, data corresponding to young researchers shows that this pattern persists, especially in the fields of Engineering and Technology, and Medical Sciences.

Graph 4. Percentage of men and women according to field of study

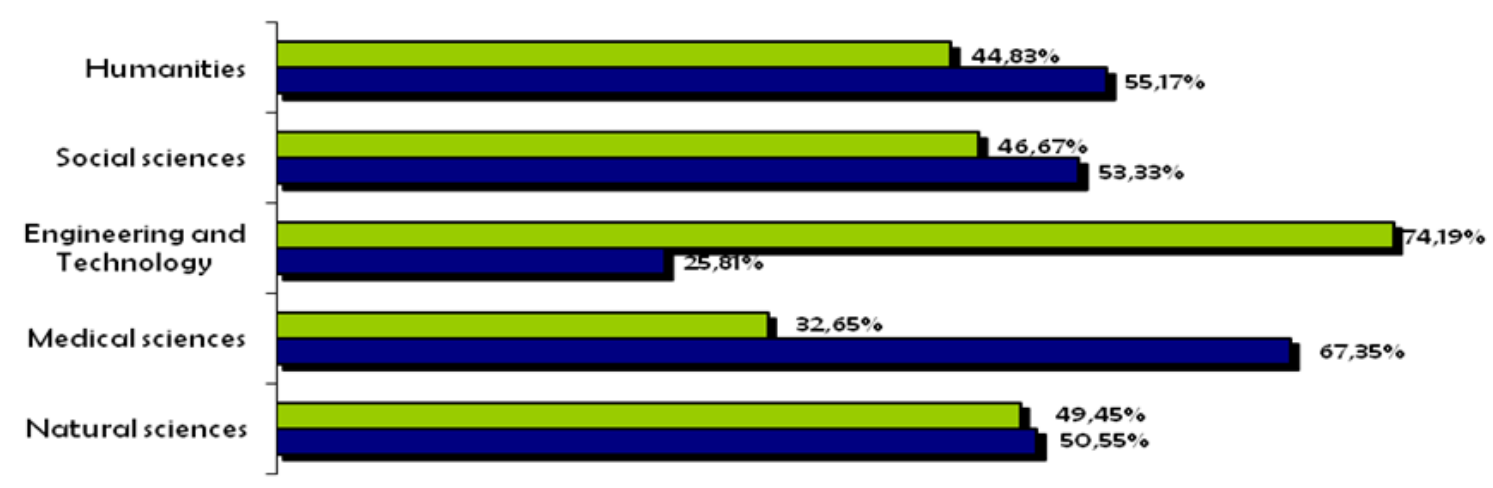


Regarding the people who began their academic career in 2005, the rate of success -understood as achieving a doctoral degree- is better for men $-44.87 \%$ of male researchers compared to $41.79 \%$ of female researchers. This indicator is coherent again with the loss of women along the academic career. Thus, the percentages of men and women who were awarded predoctoral grants were $50.91 \%$ and $49.09 \%$ respectively.

The importance of academic networks and the predominance of men in these areas of power is often emphasized by academic literature. The following graphs (5, 6, 7) show accurately the relevance of this element. The first indicator refers to the supervision the doctoral thesis. Data shows that supervisors tend to seek out men more often than women as their mentees, and that women tend to choose supervisors whose research they are interested in. Data on the access to information about grants and contracts reveals a similar pattern. Informal methods of communication prevail, and it is typically the supervisor or the academic colleagues who share the information before the official release of the grant call. Men claim more frequently to obtain information through these informal networks. These same networks are also relevant for disseminating information regarding publication opportunities. Data indicates that men publish in groups much more often than women, and that women tend to publish alone. In addition, men, much more often than women, publish in conjunction with project leaders.

Graph 5. The decision making process of thesis directors according to the sex of the interview subject

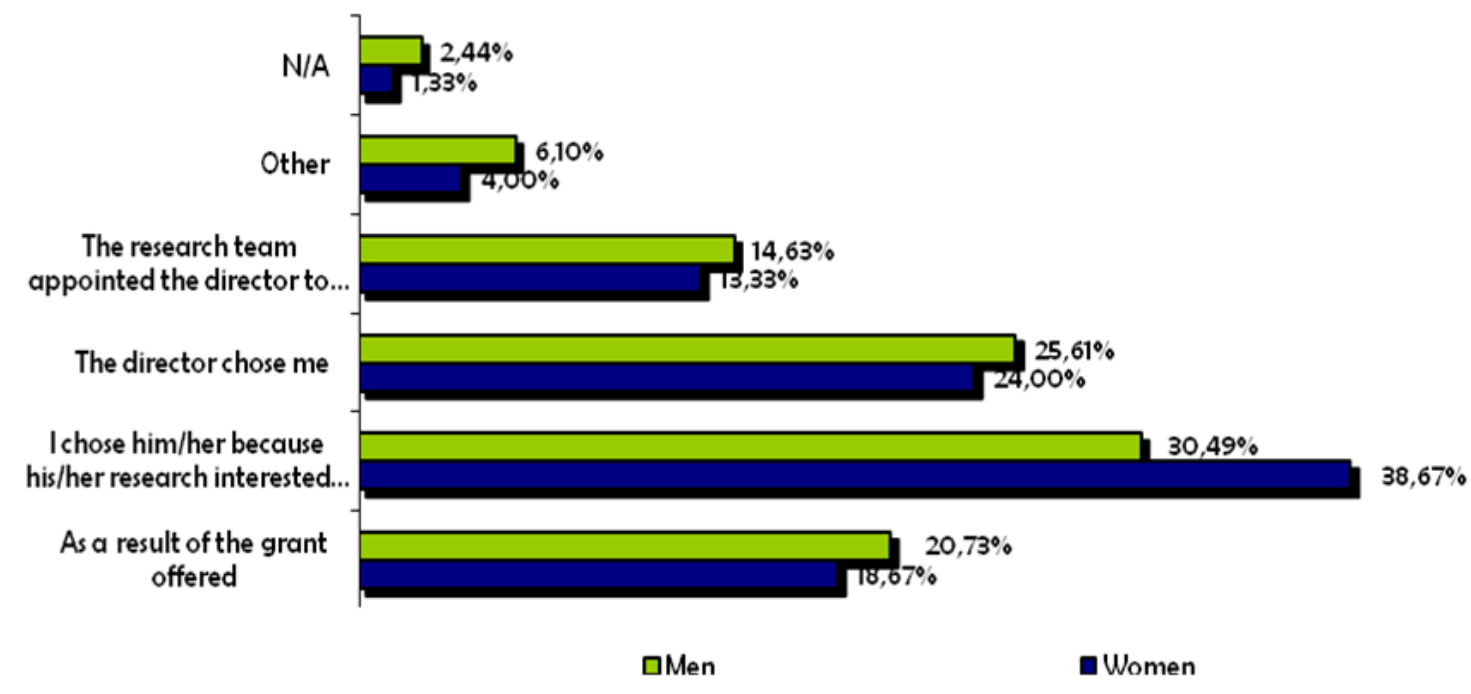

To draw this section to a close, we would like to emphasize two crucial aspects for the analysis of women's role in academia that require future investigation. First, in relation to productivity (Graph 8), data shows that during the last year men claimed to have been more productive than women: there is a greater percentage of men who publish books, articles or chapters in books, carry out research fellowships, and achieve competitive research projects. Secondly, in relation to academic positions 
(Graphs 9), there is a greater percentage of men that are accredited to be teaching assistants, lecturers and senior lecturers.

Graph 6. How did you find out about the grants or contracts according to the sex of the interview subject

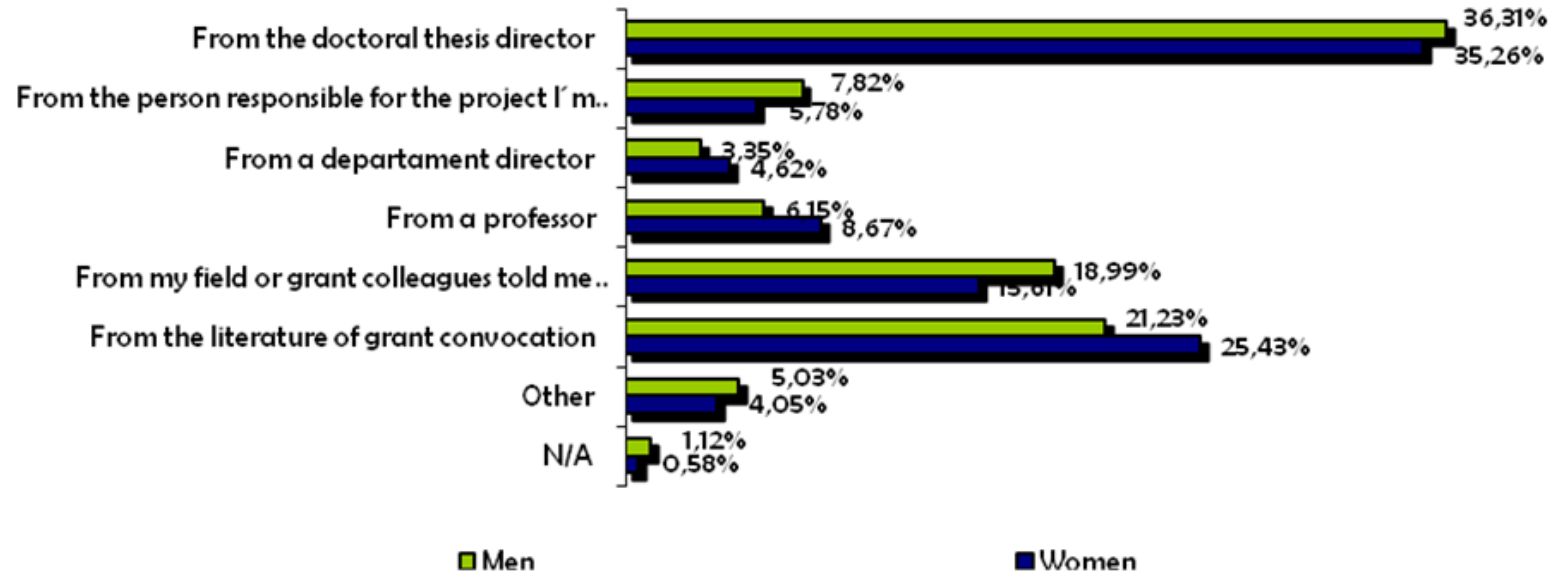

Graph 7. Method of publication according to the sex of the interview subject

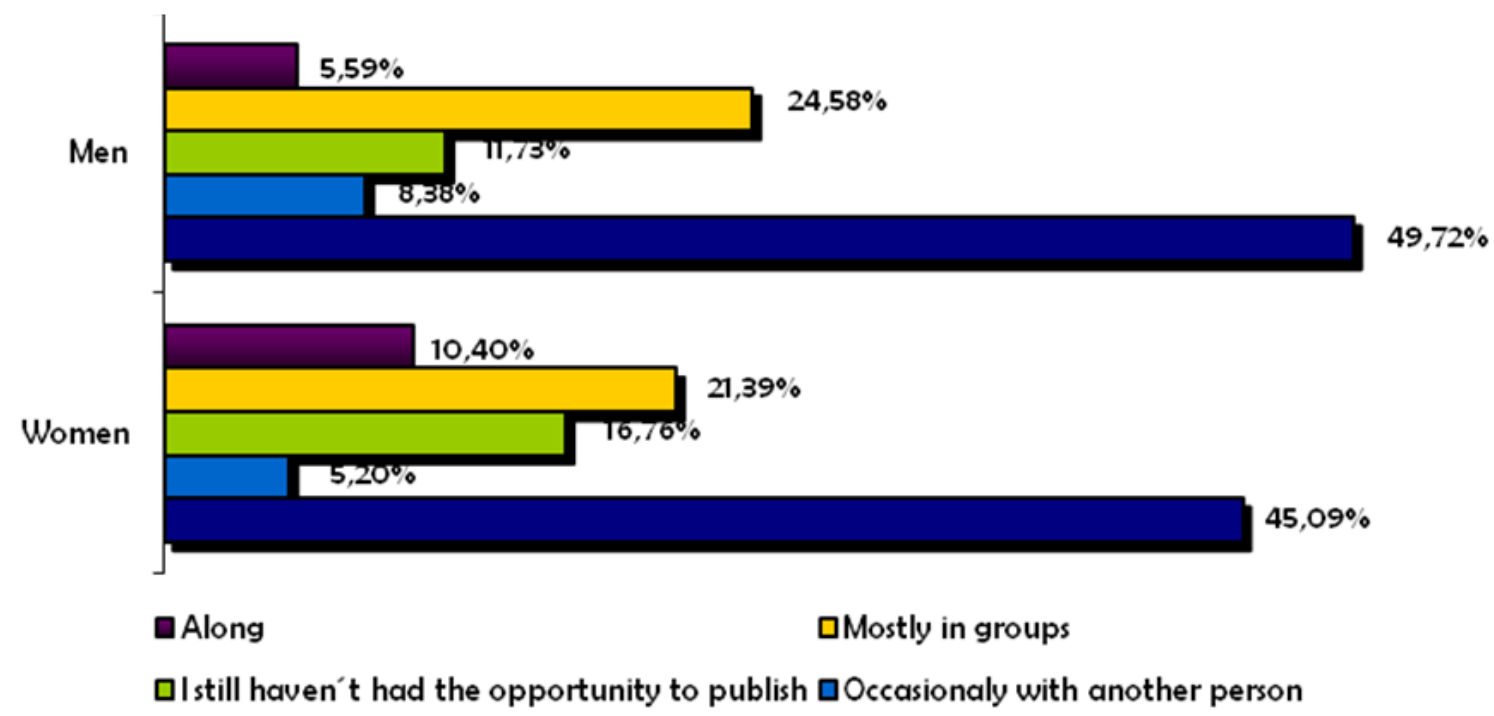

Always in groups 
Graph 8. Activities carried out during the last year according to the sex of interview subject

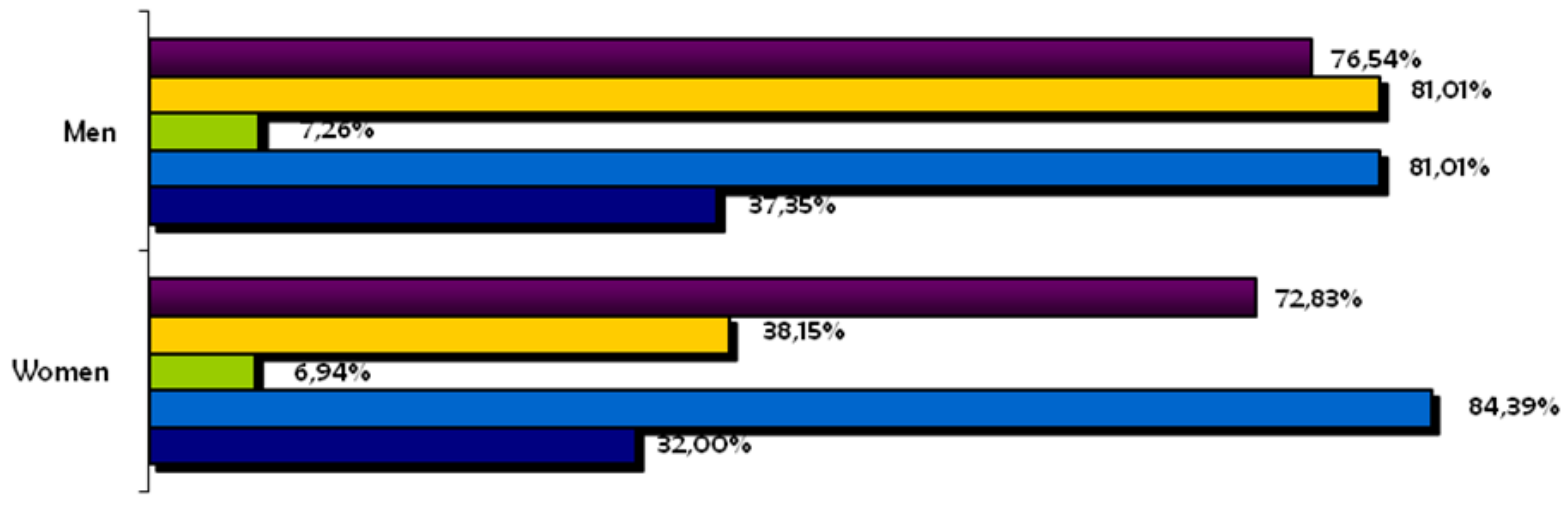

Publication of an article or chapter in a book apublication of a book

口Completion of research fellowship

-Awarded a competitive research project

口Participation in a workshop

Graph 9. Percentage of people accredited in order to be postdoctorate lectures, teaching assistants and senior university lecturer.

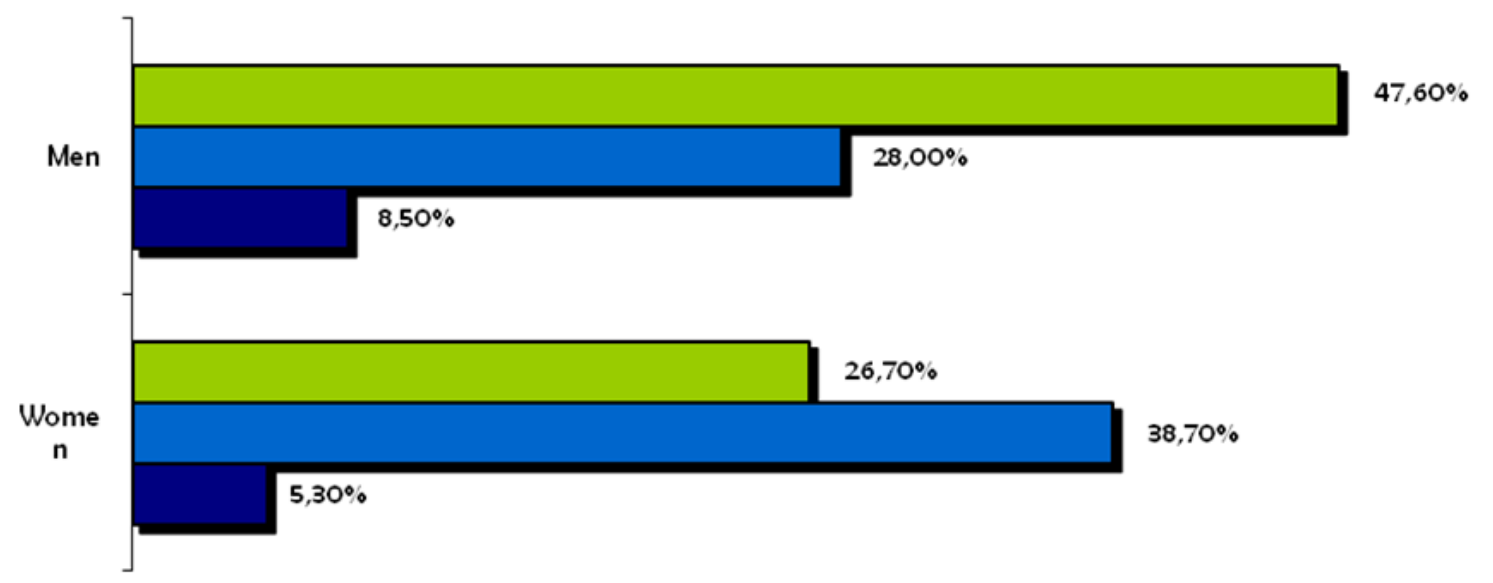

口Post-doctorate lecturer accreditation

口Post-doctorate teaching assistants accreditation

- Senior University lecturer accreditation

\section{WHAT IS THE SOLUTION FOR WOMEN IN SCIENCE? ASSESSING RESEARCH POLICIES FROM A GENDER PERSPECTIVE}

Although gender equality in science has been long considered a major topic within feminist literature, public policies began to tackle this issue just recently. The EU played a pioneering role at this respect. Equality bodies, plans, and research networks devoted to promote gender equality in the R\&D system have been in place for more than a decade (Alonso, 2015, 2016). Likewise, gender mainstreaming has 
been considered a central strategy to do so. The EU approach had a noticeable impact at the national and sub-national levels, opening the door for gender mainstreaming to be implemented in a policy field that was traditionally seen as gender-blind (Rees, 2002).

Spain is a good example of this tendency (Alonso, 2015). Generally speaking, gender mainstreaming has been adopted in the 90s, along many other countries. It started to be effectively implemented in the last decade though, also in the field of research policies (Alonso, 2015). First, multi-annual research plans included gender equality among their respective goals from 2004 onwards. The national R\&D plan approved in 2008, for instance, states that equality between men and women is a basic principle that should inform all policy measures. Research on gender inequalities, parity within decision-making bodies or a gendered evaluation of research policies appear as the key actions to put gender mainstreaming into practice in this field. Similarly, key norms like the Science and Technology Act passed in $2011^{4}$ states that recruitment processes, research designs or scientific organizations must be scrutinized not to reproduce gender inequalities. In line with the EU model, a specialized body was set up. The Women and Science unit was created in 2005 aim at improving the situation of women in science.

However, for gender mainstreaming to be effectively introduced, this general commitment to gender equality should lead to the revision of all research policies. Otherwise, it would remain as a rhetorical strategy, incapable of shaping effectively the policy-making process. An assessment of the policies implemented in this policy area provides with an accurate picture of the main measures adopted by the Spanish central government.

\section{- Reconciling professional and family life:}

R\&D policies targeted at young researchers (pre-doctoral and postdoctoral grants ${ }^{5}$ ) include measures aim at facilitating the reconciliation between professional and family life. First, in case of maternity/ paternity leave the research grant will be enlarged for the researcher to enjoy the same period of work as researchers without caring responsibilities. Thus, the idea is for care tasks not to have a negative impact on the academic career. Second, application to pre-doctoral and postdoctoral grants is limited to those researches that got a Bachelor degree or a $\mathrm{PhD}$ in a certain period normally in the last five years-. The time frame is therefore quite tight and may well discriminate against those researchers having career breaks. Consequently, calls issued by the Spanish government state that researchers who devoted a certain period to maternity/paternity leave, to look after children under six years old -in some cases under three- or family members have a broader period to apply for those grants -for instance, an extra year for each child-. These measures aim at making the academic career more flexible -to allow interruptions- in a manner that reproductive tasks are not a hindrance.

\footnotetext{
${ }^{4}$ Act $14 / 2011$ on Science, Technology and Innovation.

${ }^{5}$ FPU and FPI pre-doctoral grants, Salvador de Madariaga, Juan de la Cierva, Ramón y Cajal and Torres Quevedo postdoctoral grants and mobility grants.
} 
In this vein, Spanish research policies have been assessed not to indirectly discriminate women by ignoring the fact that female academic careers are frequently less intensive and less continuous (Probert, 2005; Elg and Jonnegard, 2003). Targeted at young researchers, they also contribute to recognize the fact that the progressive loss of women begins at these crucial stages of the academic career. Thus, pre-doctoral and postdoctoral grants are to be rethought in order to be more flexible and gendersensitive.

- Promoting gender-balance into research teams:

Programs funding research projects ${ }^{6}$ address the presence of women both as researchers and as coordinators. Evaluation committees can give extra marks -usually up to 10 points over 100- to those applications featuring a gender-balanced research team or a female team leader. This positive action aims at increasing the number of women into research projects so that they have access to resources -research networks, funding etc.- and gatekeeping positions, and improve their CVs.

- Parity into decision-making:

Most programs ${ }^{7}$, both related to research grants and project funding, introduce measures targeted at promoting women's access to decision-making positions. Evaluation and selection committees in charge of determining those projects that get funded have to be gender-balanced. These sort of positive actions have a double positive effect. First, they contribute to increase the number of women into a key position in the R\&D system. Evaluation committees decide the allocation of crucial resources such as grants, projects or positions, and more importantly, they are normally male-dominated areas (Osborn et al., 2001; Wilson and Nutley, 2003). Second, parity might potentially contribute to mitigate a gender-biased decision-making process (Wennereas and Wold, 1997).

- Changing the subject: the inclusion of a gender perspective into research projects:

The last measure refers to the inclusion of a gender perspective into research content. Industry-oriented research programs state that projects addressing Gender and Feminist Studies will be positively assessed. However, these kinds of measures are still exceptional. The three-fold EU strategy on promoting science by, for and on women is still to be further developed in Spain. Indeed, gender studies still constitute an independent area of research funding mostly financed by the Women's Institute Research Program.

Gender mainstreaming implementation has thus led to the revision of some of the key regular research policies from a gender perspective. Reconciliation between

\footnotetext{
${ }^{6}$ Includes Non-Oriented Research Projects and Complementary Actions, Applied Research Projects and Climate Change Special Action.

${ }^{7}$ Include FPI predoctoral grants, Juan de la Cierva and Ramon y Cajal postdoctoral grants, Non-Oriented Research Projects and Complementary Actions, Industry-oriented Research, Consolider and International Projects Funding.
} 
professional and private life for young researchers and parity within research teams and evaluation committees appear as the main priorities, while the introduction of a gender perspective into research projects is still a secondary goal. Attention is thus paid to the flexibilization of the academic career so that reproductive work is not a burden that disproportionately affects women, as well as to the access of female scientists to maledominated gatekeeping positions.

\section{CONCLUSIONS}

Literature on women in science has long been devoted to solve the puzzle of the persistent loss of women in academic and research institutions. This article contributes to this growing field of study by analyzing the case of Spain. It did so, first, by undertaking a diagnosis of the situation of young researchers, the key stage where the scissors diagram begins to take shape. A questionnaire was conducted to explore the hindrances, expectations and necessities of research personnel at the first stages of the academic career. It sought to capture differences among sexes that might help understand why this crucial stage constitutes the beginning of the progressive loss of women. A preliminary analysis of occurrences revealed the presence of significant differences in regards to key issues. To begin with, horizontal segregation and vertical segregation are accurately captured. Thus, women are underrepresented within some fields of knowledge and tend to decrease numbers at postdoctoral stage. On the other hand, a comparison of age average between both sexes indicates a slight slowing-down process affecting women's careers. That is, they appear to be younger than their colleagues during the doctorate studies but older than them at the postdoctoral stage. In a similar vein, when asked about their academic performance and their success in obtaining accreditations, male's numbers appear to be higher. Yet, women seem not to give up on having a family in order to improve their performance. Instead, they appear to be married and have children to a greater extent. Moreover, female researchers feature a lack of informal networks and a weaker access to information through those networks.

The second goal of the paper was to explore if and how research policies in Spain tackle gender inequalities in science. A gender perspective has been introduced into some key research policies. Plans and laws include gender equality as a general goal to be promoted. Similarly, calls in regards to research grants, research projects or travel funding have introduced pioneering gender-sensitive measures. The main issues to be tackled are the reconciliation between private and professional life, parity within research teams and evaluation committees, and the inclusion of a gender perspective into research designs. The problem of women in science appears therefore to be solved by helping young researchers to combine productive and reproductive work, by tackling women's under-representation in powerful positions and, to a lesser extent, by including a gender perspective in research content.

In light of the abovementioned diagnosis, is gender mainstreaming hitting the target? Can these policy solutions contribute to mitigate inequalities in this field? First, measures directed to reconcile private and professional life seem appropriate for 
tackling women's slower careers and their greater responsibilities in regards to care work. They contribute to make the academic career more flexible so that career-breaks or periods of low productivity do not affect women's progression. Yet, those measures refer only to doctoral and postdoctoral grants. The impact of reproductive work is only addressed in the first stages of the academic hierarchy. Scholarly works, however, have repeatedly shown the presence of the leaky pipeline throughout the academic career. Consequently, these sorts of measures should be generalized promote family-friendly academic careers.

Secondly, the lack of networks and support that female researchers perceive is likely to be diminished thanks to positive actions aimed at gender-balanced research teams. The promotion of parity within evaluation committees will also facilitate women's access to key positions within the R\&D systems. Both actions focus on breaking those 'old boys networks' that may well lie behind women's perception of isolation. Yet, indicators showing a slight lower performance, less attempts to get an accreditation or a pessimistic view of their academic career are still to be considered and properly tackled. Gendered diagnoses will be an appropriate manner of shedding light on the presence of those inequalities and the underlying processes through which they are reproduced. The research project on which this article is based constitutes a good example of how gender mainstreaming can contribute to this goal. It was funded by a research program focused on analyzing the education system, which included analyses from a gender perspective as a key research topic.

To sum up, gender mainstreaming seems to show some potential to improve the situation of female researchers. It has contributed to question key gendered components of the academic career elements, such as its design or the peer-review system. However, so far it has only led to the introduction of quite timid gendersensitive measures that are far from transforming the R\&D system. More research is needed both to keep exploring the situation of women in science, and to analyse whether existing gender-sensitive measures succeed in bringing more women to the academia.

\section{REFERENCIAS BIBLIOGRÁFICAS}

ALONSO, ALBA (2016): "Who learns what from whom? Implementing Gender Mainstreaming in Multilevel Settings”, European Journal of Women's Studies, published online 17th February.

ALONSO, ALBA (2015): El mainstreaming de género en España, Valencia: Tirant lo Blanch.

BAILYN, LOTTE. (2003): “Academia, Careers and Gender Equity: Lessons Learned from MIT”, Gender, Work and Organization, 10(2), 137-153. 
BENSCHOP, YVONNE AND BROUNS, MARGO. (2003): "Crumbling Ivory Towers: Academic Organizing and its Gender Effects", Gender, Work and Organization, 10(2), 194-212.

DEEM, ROSEMARY. (2003): "Gender, Organizational Cultures and the Practices of Manager-Academics in UK Universities”, Gender, Work and Organization, 10(2), 239-259.

EUROPEAN COMMISSION (2013): She Figures 2012. Gender in research and innovation, Brussels: European Commission.

(2009): She Figures 2009. General Information, Brussels: European Commission.

(2006): She figures 2006: Women and Science. Statistics and Indicators, Brussels: European Commission.

(2005): Women and Science: Excellence and Innovation - Gender Equality in Science, SEC(2005) 370.

ELG, ULF and KARIN JONNEGARD (2003): "The Inclusion of Female PhD Students in Academia: A Case Study of a Swedish University Department”, Gender, Work and Organization, 10(2), 154-175.

FALKENBERG, JOYCE. (2003): "Decreasing Numbers at Increasing Levels: An Investigation of the Gender Imbalance at NHH", Gender, Work and Organization, 10(2), 175-193.

GUIL et al. (2005): La Situación de las Mujeres en las Universidades Públicas Andaluzas, Sevilla: CES.

HAFNER-BURTON, EMILY and POLLACK, MARK A. (2000): "Mainstreaming Gender in the European Union”, Journal of European Public Policy, 7(3), 432456.

IZQUIERDO, MARIA JESÚS (dir.) (2009): Percepción de los factores que intervienen en la evolución de la trayectoria académica: una perspectiva de género. Instituto de la Mujer, final report.

JACQUOT, SOPHIE (2007): “Gender mainstreaming: a 'new' instrument for an 'old fashioned' policy? Towards a soft and more coordinated European gender equality policy”, Workshop Governing the EU: policy instruments in a multi-level policy, Paris, Sciences Po Paris - Centre d'études Européennes, 21-22 junio. 
KANTOLA, JOHANNA (2008): “'Why Do All the Women Disappear?' Gendering Processes in a Political Science Department”, Gender, Work and Organization, 15(2), 202-225.

(2010), Gender and the European Union, New York: Palgrave Macmillan.

LEONTOWITSCH, MIRANDA AND VÁZQUEZ-CUPEIRO, SUSANA (2003a): "Above the Glass Ceiling? Peliminary report of Postal Survey of University Professors in the UK”, http://csn.uni-muenster.de/womeneu/download/TP\%2003-13/20Leontowitsc/20Vasquez-Cupeiro.pdf

LEONTOWITSCH, MIRANDA AND VÁZQUEZ-CUPEIRO, SUSANA (2003b):”Merit, luck, and a good Nanny? Exploring the Intricacies in the career trajectories of Women Academics in Psicology and Engeneering”, http://csn.unimuenster.de/women-eu/download/TP\%2003-13/20Leontowitsc/20VasquezCupeiro.pdf

MARTÍNEZ COSTA, CARME (dir.) (2003): Llibre blanc de les dones de Catalunya en el món de la ciència i la tecnologia, Barcelona: Institut Català de la Dona.

MAZEY, SONIA (2001): Gender mainstreaming in the EU. Principles and Practice, Londres: Kogan.

OSBORN, MARY et al. (2001): Informe Política Científica de la Unión Europea. Promover la excelencia mediante la integración de la igualdad entre géneros, Bruselas: Oficina de publicaciones oficiales de las Comunidades Europeas.

PROBERT, BELINDA (2005): “'I Just Couldn't Fit In': Gender and Unequal Outcomes in Academic Careers”, Gender, Work and Organization, 12(1), 50-72.

REES, TERESA (dir.) (2002): Grupo de Helsinki sobre mujeres y ciencia: Políticas nacionales sobre mujer y ciencia en Europa, Luxemburgo: Oficina de publicaciones oficiales de las Comunidades Europeas.

SQUIRES, JUDITH (2007): The new politics of gender equality, New York: Palgrave Macmillan.

UNESCO (2007): Women Science Technology and Gender. An international report, Paris: UNESCO Publishing.

UNIDAD DE MUJER Y CIENCIA (2014): Científicas en cifras 2013, Madrid: Ministerio de Economía y Competitividad.

UNIDAD DE MUJER Y CIENCIA (2011): Científicas en cifras 2011, Madrid: UMyC. 
VÁZQUEZ, ELENA et al. (2009): Women in the Galician Education System: current situation, Madrid: FECYT.

WENNEREAS, CHRISTINE AND WOLD, AGNES (1997): Nepotism and sexism in peer-review, Nature, vol. 387, 341-343.

WILSON, FIONA AND NUTLEY, SANDRA (2003): A Critical Look at Staff Appraisal: The Case of Women in Scottish Universities. Gender, Work and Organization, 10(3), 301-319. 